\title{
Pengambilan Keputusan Guna Mencegah Penyakit Diabetes Melitus
}

\author{
Najla Asyah Syafawani Lubis/191101010
}

\author{
najlaasyahsyafawani@gmail.com
}

\section{Latar Belakang}

Diabetes Melitus telah menjadi masalah kesehatan di Indonesia, bukan hanya di Indonesia tetapi menjadi masalah kesehatan di dunia. Diabetes melitus adalah penyakit yang ditandai dengan terjadinya hiperglikemia dan gangguan metabolisme karbohidrat, lemak, dan protein yang dihubungkan dengan kekurangan Secara absolut atau relatif dari kerja dan atau sekresi insulin. Gejala yang dikeluhkan pada penderita diabetes melitus yaitu polidipsia, polifagia, penurunan berat badan, dan kesemutan (Restyana,2015). Diabetes melitus tipe 2 merupakan tipe diabetes yang paling umum ditemukan pada pasien dibanding dengan diabetes melitus tipe 1 diabetes gestasional dan diabetes tipe lain (Richardo,Damayanti, dan Nelly,2014).

Meskipun penyakit diabetes melitus bukan penyebab kematian nomor satu di Indonesia tapi penyakit ini merupakan penyakit yang tetap harus diwaspadai. Hal ini karena penyakit tersebut bisa dapat menjadi suatu awal dari penyakit lainnya bahkan di beberapa kasus komplikasi yang disebabkan oleh diabetes lah yang paling sering menyebabkan kematian sebenarnya banyak tindakan tindakan pencegahan yang seringkali diabaikan oleh para penderitanya.

Tingginya prevalensi diabetes melitus disebabkan oleh faktor risiko yang tidak dapat berubah misalnya jenis kelamin, umur, dan faktor genetik. Yang kedua adalah faktor risiko yang dapat diubah misalnya kebiasaan merokok, tingkat pendidikan, pekerjaan, aktivitas fisik, mengonsumsi alcohol, indeks massa tubuh. Diabetes melitus disebut dengan the silent killer karena penyakit ini dapat mengenai semua organ tubuh dan menimbulkan berbagai macam keluhan. Penyakit yang akan ditimbulkan antara lain gangguan penglihatan mata, katarak, penyakit jantung, sakit ginjal, impotensi seksual, luka sulit sembuh dan membusuk, infeksi paru-paru, gangguan pembuluh darah, stroke dan sebagainya (Restyana,2015). Penyebab diabetes melitus paling banyak ditemui adalah pola hidup yang tidak sehat. Oleh karena itu perlu adanya pengambilan keputusan guna mencegah penyakit diabetes melitus ini. 


\section{Metode}

Rancangan penugasan kajian ini menggunakan metode penelitian deskriptif. Metode penelitian deskriptif ini dapat menyelesaikan suatu masalah dengan pengumpulan data, menganalisa, membandingkan sehingga dapat menentukan pengambilan keputusan dalam masalah tersebut. Yang berdasarkan dari penjelasan sumber dan referensi yaitu berupa jurnal, ebook atau buku teks.

\section{Hasil}

Berdasarkan data RISKESDAS menyebutkan prevalensi dari penderita diabetes melitus meningkat pada perempuan dibanding dengan laki-laki dan terjadi peningkatan prevalensi cenderung lebih tinggi bagi penderita yang tinggal di perkotaan dibanding di pedesaan. Jika ditinjau dari segi pendidikan menurut RISKESDAS bahwa prevalensi diabetes melitus cenderung lebih tinggi pada masyarakat yang tingkat pendidikan tinggi serta dengan indeks kepemilikan yang tinggi (RISKESDAS,2013). Hasil data dari RIKESDAS ini juga sejalan dengan penelitian lainnya di mana perempuan cenderung lebih beresiko memiliki penyakit diabetes melitus dan diabetes gestasional(Diani,Waluyodan Sukmarini,2013).

Berdasarkan hasil pencarian literatur berbagai sumber didapatkan bahwa sangat penting dilakukannya pencegahan penyakit diabetes melitus ini. Karena diabetes melitus merupakan gangguan proses metabolisme gula darah yang berlangsung kronik ditandai dengan tingginya kadar gula darah yang diakibatkan oleh gangguan pengeluaran insulin, resistensi insulin atau keduanya. Sehingga dikhawatirkan terjadi kerusakan mata, ginjal, jantung dan syaraf bila kadar gula darah tetap tinggi. Penderita diabetes melitus dapat mengalami gangguan fungsi jantung yang berakibat kematian iskemik dan stroke lebih berpotensi dua sampai empat kali daripada populasi yang yang tidak mengalami diabetes melitus (Bilous dan Donelly, 2010).

Ada beberapa faktor resiko diabetes melitus yaitu usia, obesitas, makanan, aktivitas fisik, gaya hidup (Richardo,Damayanti dan Nelly, 2014). Oleh karena itu diabetes melitus ini sangat perlu diadakannya upaya-upaya pencegahan. Salah satu upaya pencegahannya ialah dengan melakukan pendidikan kesehatan yang bertujuan untuk meningkatkan status kesehatan dan mencegah timbulnya penyakit mempertahankan derajat kesehatan yang sudah ada mengoptimalkan fungsi 
dan peran pasien selama sakit dan membantu pasien serta keluarga untuk mengatasi masalah kesehatannya.

\section{Pembahasan}

Diabetes melitus adalah penyakit kronik progresif yang ditandai dengan peningkatan kadar glukosa darah hiperglikemia akibat penurunan sekresi dan atau aktivitas insulin yang dilatarbelakangi oleh resistensi insulin. Pada diabetes melitus terjadi abnormalitas metabolisme karbohidrat, lemak, dan protein akibat kekurangan insulin pada jaringan target diabetes melitus juga ditandai dengan terjadinya stres oksidatif, inflamasi, dan disfungsi Sel Beta pankreas. Penyakit ini merupakan salah satu penyakit yang menyebabkan peningkatan risiko kematian dan penurunan kualitas hidup akibat berbagai komplikasi serius (Ayuwardani dan susilowati,2018).

Ada beberapa gambaran faktor resiko diabetes melitus yaitu: pertama usia, diabetes mellitus dapat menyerang warga penduduk dari berbagai lapisan, baik dari segi ekonomi rendah, menengah ,atas ,ada pula dari segi usia.tua maupun muda dapat menjadi penderita diabetes melitus titik umumnya manusia mengalami perubahan fisiologi yang secara drastis menurun dengan cepat setelah usia 40 tahun titik diabetes sering muncul karena seseorang memasuki usia rawan, terutama setelah usia 45 tahun pada mereka yang berat badan yang berlebih, sehingga tubuhnya tidak peka lagi terhadap insulin.teori yang ada mengatakan bahwa seseorang yang $>45$ tahun memiliki peningkatanresiko terhadap terjadinya diabetes melitus dan intoleransi glukosa yang disebabkan oleh faktor degeneratif yaitu menurunnya fungsi tubuh, khususnya kemampuan dari sel beta dalam memproduksi insulin . untuk metabolisme glukosa (Betteng, Pengemanan, Mayulu, 2014).

Kedua obesitas, obesitas bukan hanya mengundang penyakit jantung koroner dan hipertensi,tetapi juga diabetes melitus. obesitas merupakan faktor utama dari insiden diabetes melitus. obesitas dapat terjadi karena banyak faktor .faktor utama adalah ketidakseimbangan asupan energi dan keluarnya energi. obesitas juga melibatkan beberapa faktor ,antara lain: genetik ,lingkungan psikis, perkembangan, lifestyle ,kerentanan terhadap obesitas termasuk program diet, usia, jenis kelamin, status ekonomi ,dan penggunaan kontrasepsi khususnya kontrasepsi hormonal. ndeks massa tubuh secara bersama-sama dengan variabel lainnya mempunyai hubungan yang signifikan dengan diabetes melitus. penelitian sebelumnya yang 
dilakukan oleh Sanjaya, menemukan bahwa individu yang mengalami obesitas mempunyai risiko 2,7 kali lebih besar untuk terkena diabetes melitus dibandingkan dengan individu yang tidak mengalami masalah obesitas (Betteng, Pengemanan, Mayulu, 2014).

Ketiga makanan, teori menyebutkan bahwa seringnya mengkonsumsi makanan/ minuman manis akan meningkatkan resiko kejadian diabetes melitus karena meningkatkan konsentrasi glukosa dalam darah.riwayat pola makan yang kurang baik juga menjadi faktor resiko penyebab terjadinya diabetes melitus pada wanita usia produktif yang sering diungkapkan oleh informan. makanan yang dikonsumsi diyakini penyebab meningkatnya gula darah . perubahan diet, seperti mengonsumsi makanan tinggi lemak menjadi penyebab terjadinya diabetes, terutama di daerahdaerah. Pemilihan makanan harus dilakukan secara bijak dengan melaksanakan pembatasan kalori,terutama pembatasan lemak total dan lemak jenuh untuk mencapai kadar glukosa dan lipid darah yang normal. Secara umum komposisi menu yang direkomendasi oleh who tahun 1990 terdiri $50-65 \%$ karbohidrat, $25-30 \%$ lemak dan $10-20 \%$ protein (Betteng, Pengemanan, Mayulu, 2014). Pola hidup remaja kini cenderung kurang teratur dan beresiko menyebabkan diabetes di kemudian hari, remaja sekarang gemar mengonsumsi fast food maupun junk food yang bisa terjadinya beresiko diabetes.

Keempat aktivitas fisik, ktivitas fisik dapat mengontrol gula darah . glukosa akan diubah menjadi energi pada saat beraktivitas fisik.aktivitas fisik mengakibatkan insulin semakin meningkat sehingga kadar gula dalam darah akan berkurang titik pada orang yang jarang berolahraga, zat makanan yang masuk ke dalam tubuh tidak terbakar tetapi ditimbun dalam tubuh sebagai lemak dan gula.jika insulin tidak mencukupi untuk mengubah glukosa menjadi energi maka akan timbul diabetes melitus. Selain kurangnya aktivitas fisik yang dilakukan, konsumsi makanan beresiko, konsumsi alkohol dan rokok menjadi risiko diabetes melitus (Betteng, Pengemanan, Mayulu, 2014). Pada zaman sekarang remaja lebih kecanduan game yang menyebabkan malasnya beraktifitas sehingga dapat menimbulkan resiko diabetes.

Kelima gaya hidup, pakar penyakit diabetes melitus sidartawan soegondo berpendapat bahwa peningkatan jumlah penderita diabetes yang cukup tinggi ini dipicu oleh gaya hidup yang tidak sehat yakni gerak fisik yang dilakukan . gaya hidup seperti ini mudah menimbulkan kegemukan . dengan berat badan berlebih, resiko seseorang terkena diabetes juga semakin meningkat (Betteng, Pengemanan, Mayulu, 2014). Remaja sekarang cenderung melakukan gaya hidup 
modern yang serba santai, instan, dan canggih. Makin beragamnya jenis makanan yang manis, dan berkolesterol tinggi serta ditambah dengan adanya teknologi canggih membuat Semuanya serba otomatis. Gaya hidup tersebut dapat menjadikan faktor yang meningkatkan individu tanpa riwayat diabetes terjangkit diabetes (Gustaviani, 2006).

Diabetes yang tidak terkontrol dengan baik akan menimbulkan komplikasi akut dan kronis menurut PERKENI komplikasi diabetes melitus dapat dibagi menjadi dua kategori : Komplikasi akut yaitu hipoglikemia dan hiperglikemia. Sedangkan komplikasi kronis yaitu komplikasi makrovaskuler dan komplikasi mikrovaskuler. Hipoglikemia adalah kadar glukosa darah seseorang di bawah nilai normal. Hiperglikemia adalah apabila kadar gula darah meningkat secara tiba-tiba dapat berkembang menjadi keadaan metabolisme yang berbahaya. Sedangkan komplikasi makrovaskuler yang umum berkembang pada penderita diabetes melitus adalah trombosit otak atau pembekuan darah pada sebagian otak mengalami penyakit jantung koroner gagal jantung kongestif dan stroke. Komplikasi mikrovaskuler terutama terjadi pada penderita diabetes melitus tipe 1 seperti nefropati, diabetik retinopati (kebutaan) dan amputasi (Fatimah, 2015).

Oleh karena itu harus adalah pengambilan keputusan guna mencegah penyakit diabetes mellitus ini. Ada beberapa pengambilan keputusan guna untuk mencegah penyakit diabetes mellitus yaitu: Pertama Pencegahan Premordial, adalah upaya untuk memberikan kondisi pada masyarakat yang memungkinkan penyakit tidak dapat dukungan dari kebiasaan, gaya hidup dan faktor risiko lainnya. Pencegahan premordial pada penyakit diabetes melitus misalnya adalah menciptakan prakondisi sehingga masyarakat merasa bahwa konsumsi makanan ke barat-baratan adalah suatu pola makan yang kurang baik, pola hidup santai atau kurang aktivitas, dan obesitas adalah kurang baik bagi kesehatan. Kedua Pencegahan primer, adalah upaya yang ditujukan pada orang-orang yang termasuk kelompok resiko tinggi yaitu mereka yang belum menderita diabetes melitus tapi berpotensi untuk penderita diabetes melitus. Ketiga Pencegahan tersier adalah upaya mencegah terjadinya kecatatan lebih lanjut dan rehabilitasi pasien sedini mungkin sebelum kecacatan tersebut menetap. pelayanan kesehatan yang holistik dan integrasi antar disiplin terkait sangat diperlukan, terutama di rumah sakit rujukan, misalnya para ahli sesama disiplin ilmu seperti ahli penyakit jantung mata rehabilitasi medis gizi dan lain-lain. Keempat Pencegahan sekunder, adalah upaya mencegah atau menghambat timbulnya penyulit dengan tindakan deteksi 
dini dan memberikan pengobatan sejak awal penyakit. Dalam pengelolaan pasien diabetes melitus sejak awal sudah harus diwaspadai dan sedapat mungkin dicegah kemungkinan terjadinya penyulit menahun. Pilar utama pengelolaan diabetes melitus meliputi penyuluhan, perencanaan makanan, latihan jasmani, obat berhasiat hipoglikemik (Fatimah, 2015). Pendidikan kesehatan tentang diabetes melitus merupakan pilar untuk meningkatkan pengetahuan sikap dan upaya pencegahan diabetes melitus pendidikan kesehatan tentang diabetes melitus secara terencana, individu kelompok dan masyarakat dapat lebih patuh dalam mencegah diabetes melitus sehingga status kesehatan tetap terjaga. Pendidikan kesehatan tentang diabetes melitus adalah Pendidikan dan Pelatihan mengenai pengetahuan dan keterampilan pencegahan diabetes melitus bagi masyarakat yang bertujuan menunjang perubahan perilaku sehingga tercapai kualitas hidup yang lebih baik pendidikan kesehatan yang diberikan secara terus-menerus dapat berkontribusi terhadap keberhasilan pencegahan diabetes melitus semakin sering seseorang mendapatkan pendidikan kesehatan tentang diabetes melitus maka semakin baik pula pencegahan diabetes mellitus (Rosyid, Hudiawati,dan Kristinawati 2019). Dalam pendidikan kesehatan peran perawat sebagai edukator sangat penting dalam upaya mendukung keberhasilan perilaku perawatan diri bagi pasien diabetes ini diharapkan dengan informasi yang baik dari perawat dan petugas kesehatan lainnya para diabetes akan memiliki pengetahuan yang baik sehingga dapat mencegah komplikasi secara mandiri (Soegondo, 2011).

\section{Kesimpulan}

Diabetes melitus merupakan penyakit yang tidak menular tapi penyakit ini harus di waspadai. Upaya penatalaksanaan diabetes melitus tidak hanya berfokus pada Penanganan dan pengendalian penyakitnya saja melainkan harus berfokus juga pada upaya pencegahannya terutama pada populasi yang beresiko. Salah satu peran perawat ialah Sebagai edukator yang bertanggung jawab dalam upaya peningkatan kualitas kesehatan peran perawat sebagai edukator merupakan salah satu dari peran dalam melakukan edukasi atau pendidikan kesehatan pendidikan kesehatan ini merupakan komponen yang esensial dalam asuhan keperawatan yang diarahkan kepada kegiatan meningkatkan kesehatan mencegah penyakit dan membantu individu mengatasi efek sisa maupun komplikasi yang ditimbulkan akibat penyakitnya. 


\section{Daftar Pustaka}

Awad, N., Langi, Y, A., Pandelaki, K. (2013). Gambaran Faktor Resiko Pasien Diabetes Melitus Tipe II di Poliklinik Endokrin Bagian/SMF FK-UNSRAT RSU Prof. Dr. R.D Kandou Manado. Jurnal e-Biomedik, 1 (1), 45-49.

Ayuwardani, N., Susilowati., (2018). Pengaruh Pola Makan Terhadap Kadar Malondialdehid Plasma Sebagai Upaya Pencegahan Diabetes Melitus Di Usia Remaja. Jurnal Keperawatan, 11 (2), 27-32.

Betteng, R., Pengemanan, D., Mayulu, N. (2014). Analisis Faktor Resiko Penyebab terjadinya Diabetes Melitus Tipe 2 Pada Wanita Usia Produktif Di Puskesmas Wawonasa. Jurnal eBiomedik, 2 (2), 404-412.

Fatimah, R, N., (2015). Diabetes Melitus Tipe 2. J Majority, 4 (5), 93-100.

Lestari, R., Sari, C., Kurniawan, T. (2018). Gambaran Persepsi Mahasiswa terhadap Perilaku Pencegahan Diabetes Melitus Di Fakultas Keperawatan Universitas Padjadjaran. Jurnal Pendidikan Keperawatan Indonesia, 4 (1), 69-75.

Lufthiani.,Karota, E., Sitepu, N, F. (2020). Panduan Konseling Kesehatan: Dalam Upaya Pencegahan Diabetes Melitus. Yogyakarta: Deepublish.

Oxyandi, M., (2014). Analisis Determinan Perilaku pasien dalam pencegahan komplikasi Penyakit Diabetes Melitus. Jurnal Kebidanan dan Keperawatan, 10 (2), 154-162.

Rosyid, F., Hudiawati, D., Kristinawati, B. (2019). Peningkatan Pengetahuan Dan Upaya Pencegahan Diabetes Melitus Melalui Pendidikan Kesehatan. Jurnal Pengabdian Kepada Masyarakat, 7 (2), 91-94.

Sari, R.,Nuryati, E., (2016). Komitmen Pencegahan Diabetes Mellitus. Jurnal Ilmiah Kesehatan, $5(9), 622-632$.

Silalahi, L., (2019). Hubungan Pengetahuan dan Tindakan Pencegahan Diabetes Mellitus Tipe 2. Jurnal Promkes, 7 (2), 223-232.

Simamora, R. H. (2019). Menjadi perawat yang: CIH'HUY. Surakarta: Kekata Publisher. 
Simamora, R. H.(2005). Hubungan Persepsi Perawat Pelaksana Terhadap Penerapan Fungsi Pengorganisasian Yang Dilakukan Oleh Kepala Ruangan Dengan Kinerjanya Diruang Rawat Inap RSUD Koja Jakarta Utara (Doctoral dissertation, Tesis FIK UI, Tidakdipublikasikan). 